International Journal of Linguistics, Literature and Translation

ISSN: 2617-0299 (Online); ISSN: 2708-0099 (Print)

DOI: $10.32996 /$ ijllt

Journal Homepage: www.al-kindipublisher.com/index.php/ijltt

IJLLT

\title{
Peer Correction Technique in Encouraging the Indonesian EFL Learners to Write Compositions
}

\author{
Rafi'ah Nur \\ English Language Education Department of Graduate Program Universitas Muhammadiyah Parepare, Indonesia \\ $\square$ Corresponding Author: Rafi'ah Nur, E-mail: rafiahnur@yahoo.com
}

\section{ARTICLE INFORMATION \\ Received: 17 September 2021 \\ Accepted: 14 October 2021 \\ Published: 30 October 2021 \\ DOI: $10.32996 /$ ijllt.2021.4.10.23}

\section{KEYWORDS}

Peer-correction technique, writing, Indonesian EFL learners.

\section{ABSTRACT}

In writing an essay, a writer is demanded to consider several essential aspects of writing. They are mechanics, contents, coherence, organization, grammar, and vocabulary (Harmer, 2001, p. 88). Because of these demands on writing an essay, learners who are training their writing skills may face various problems in the process of writing an essay. Moreover, it is important to notice that many ESL students consider writing as hard and become suspicious when faced with writing assignments; thus, they often refuse to take time to write (Rankin-Brown, 2006). This research aims to discover how peer correction helps students find and reduce their mistakes in composing a recount text. This research used a quasi-experimental method. The population was the students of senior high school in Sidrap regency, Indonesia. The total population was 178 students from seven classes, and this research assigned two groups, namely experimental and control groups. The sample was selected by using a cluster random sampling technique. This research found that the students experienced some difficulties in arranging paragraphs and using grammar. They made many mistakes in their writings in terms of grammar, diction, coherence, organization, and they also lacked vocabulary. The problem is that they did not realize or do not know the mistakes that they have produced. By applying the peer correction technique, the students may experience the four elements in the writing process. The peer correction technique will facilitate the students to know either the strengths and the weaknesses they have made. This technique also helps them identify what was missing from their drafts so they can make corrections, revisions, and improvements to their writings. In addition, students with their partners could exchange their writing to verify the organization in writing. The research concluded that using peer correction technique is sufficient to reduce the students' mistakes in writing recount text of senior high school students in Sidrap, Indonesia.

\section{Introduction}

Writing serves as an essential form of communication in the modern era, which can replace oral communication (Vermeir et al. 2015). This belief was confirmed by Sadeghi and Richards (2016), who argued that the written language nowadays has an essential social and educational function. They believe that written language plays a high social prestige status.

Writing is one of the important skills in studying a new language (Zeng, 2016; Ayu and Ari, 2018). It is a productive skill and activity carried someone to express their thoughts and feelings to gain knowledge and experience through written language (Astawa et al., 2017); (Nona \& Chalak 2016). As a communication tool, writing requires comprehensive skills to get excellent communication (Ying 2018). Therefore, a writer must master the correct writing procedures. (Troia and Graham 2004; Harris and Graham 2016). Harmer (2007), on the essentiality of the writing skill, stated that the idea to teach writing to EFL learners involves reinforcement, language development, learning style, and, most importantly, writing as a skill in its own right. Therefore, students should learn the art of good writing as the essential order at both academic and professional levels (Hyland 2016).

Copyright: (c) 2021 the Author(s). This article is an open access article distributed under the terms and conditions of the Creative Commons Attribution (CC-BY) 4.0 license (https://creativecommons.org/licenses/by/4.0/). Published by Al-Kindi Centre for Research and Development, London, United Kingdom. 
Hussein (2015) stated that writing is an activity of expressing ideas through language features. Therefore, the writer must have the capability to use vocabulary in this productive and expressive activity (Kennedy and Shiel 2019); (Maskor and Baharudin 2016). So, writing and language structure. (Stefano 2020) states that writing skills as the act of moving thoughts and feelings into written language by using symbols. In line with this opinion, according to (Jacobson-Lundeberg 2016), skills are defined as the ability to use ideas, thoughts, or feelings to others by using written language. Writing is an activity of expressing ideas, thoughts, or feelings into the symbols of language (Carosotto 2017). It is an extremely complex cognitive activity in which the writer must be available to demonstrate control of variables simultaneously (Rao 2018; V Satya Sri Durgndra Sekhar and Rao 2018). At the sentence, it consists of control of the contents, format, sentence structure, vocabulary, spelling, and letter formation (Ibrahim Mohamed Alfaki 2015) Beyond the sentence, the writer must be able to structure and integrate information into cohesive and coherent paragraphs and text (Faradhibah and Aliyah 2017). Therefore, good writing skill is demanded by many people to accomplish specific types of writing like writing an essay, a paper, a proposal, and an application form. (Latifa, Ernawati, and Budiman 2020).

\section{Literature Review}

\subsection{Teaching Writing}

Rivers (1968, p.2463), Sharp (2016) stated that writing refers to the construction ideas, which organize the graphic conventions of the language systematically; the intentional academic of the writer at this discussion is to encourage to express him in a polished literary form which requires the utilization of a particular vocabulary and specific refinement structure. Furthermore, (Jordan et al. 1990) claimes that writing as, "...the method of human intercommunication utilizing conventionally visible marks". Similarly, Fadhly. F.Z and Ratnaningsih (2018) stated that writing is far from being a simple matter of language transcription into written symbols: it is a thinking activity to its right. Writing is one of a permanent record, as an arrangement of expression and as a tool of communication. Some essential aspects such as the content of the essay, organization of the essay, coherence, grammar, vocabulary, and mechanics should be considered in the process of composing an essay writing (Harmer, 2001: 88). Due to these various aspects of essay writing, learners may face problems in the process of composing an essay writing (Lalam 2019). and it is essential to notice that many ESL students regard writing as difficult and become suspicious when assigned to a writing task and, thus, often avoid spending time on writing (Rankin-Brown, 2006). The problems with writing difficulty can become more prevalent at the college level, whereby students must undertake more mature and sophisticated academic writing to match their perceived level of intelligence (Ismail et al., 2012). Oshima et al. (2006) assert that the students' writings often consist of four-sentence problems, namely a fragment, run-on sentences, choppy sentences, and stringy sentences. The grammatical errors that often occur in students' writing are errors in the use of concord, finite verbs, tenses, verb groups, articles, punctuation, and spelling. The semantic problems, meanwhile, are the clumsiness (word-by-word translation), the inter-language interference, the indirectness, and the expressiveness.

Through writing, people can convey ideas, knowledge, and feelings to others (E Ackerman 2019). As asserted by (Brown 2001), the teacher's role in teaching writing is to encourage students to develop their ideas in writing. Many students encounter many problems when they start writing, especially in writing recount text. Byrne (1993) asserts that writing is difficult for students because they are required to write on their writing, struggling by themselves to refine their writings without any interaction or feedback from either other friends or teachers. For example, the students spend a lot of time thinking about what they will write and what words they should use because they cannot come up with ideas quickly (Badcock and Stoller 1989). They also have many errors or mistakes in composing writing. It is because they practice writing rarely and do not carefully correct theirs on writing. Also, they may not be able to put their ideas cohesively in a text.

\subsection{Peer Correction Technique in Teaching Writing}

The conventional teacher learning method, which explains more material with lectures, turns out to hurt the quality of the process and learning outcomes of writing (Latifa 2019) (Darling-Hammond 2017). This phenomenon is evident from the low activity, attention, interest, and motivation of students in learning to write as well as the low student learning outcomes in writing material (Genlott and Grönlund 2013; Judith and Jessi, 2016)

The teacher often expresses his reflection on the results of student writing when distributing writing (Ullmann 2019). However, it does not have much impact because, in reality, the teacher still often encounters various forms of language errors in the writing of the next student (Alfaki, 2015; Fareed et al., 2016). The teacher states that he has not yet found the right learning technique to improve students' mastery of the rules of written language so that the value of writing scientific papers increases students. The teacher also complained about his difficulties in attracting students' interest and activeness in learning to write scientific papers (Imaniah et al., 2019). Based on information obtained from teachers and students, researchers suggest that teachers apply peercorrection techniques in learning to write scientific papers. The peer-correction is a learning technique that directs students to correct language errors in their friends' writing with the help of indirect feedback from the teacher (Al-saleh, 2018); Amara, 2015). In a study conducted by Hajan et al. (2019), the recommended form of feedback is the giving of signs or symbols of language errors in the margins of student writing (Hajan et al., 2019). Thus, students are more directed at correcting and more easily 
recognize language errors in the writing of their friends (Ines 2017). This peer-correction technique is recommended because, based on the teacher's comprehension, he always applies a direct correction technique or teacher correction in learning to write scientific papers so far (Banaruee et al., 2018). It is the teacher who identifies the positions of the errors, discovers the cause of errors, and adjusts the language errors in the students' written results (Charles Owu-Ewie and Miss Rebecca Williams 2017). That is, the given feedback by the teacher to student writing is direct (in the form of direct feedback) (Westmacott 2017). Further, Méndez García et al. (2018), Arifin and As'ad (2019) suggest that this method inhibits students from learning actively and creatively because students do not have the opportunity to use teacher feedback to correct errors in language. Gestanti et al. (2019); Jingjing (2017) add that learners will experience confusion if they are not given feedback when they cannot consider which is wrong.

Feedback in the peer-correction technique plays an essential aspect in language learning. Boyd (2015) asserts that feedback is an important thing that must occur in functional learning interaction. Kuyyogsuy (2019) and Jingjing (2017) confirm that the peercorrection technique shows the students' activities or busyness in reading their friends' writings then replaying them in the form of corrections in their positions as readers. Moreover, Walz and Date (1982) mention various forms of application of peer correction techniques. They are the use projection of media, discussion in groups, exchange writing of peers, and writing in groups. In this study, the peer-correction technique suggested by researchers to be applied by teachers to write scientific papers is the third technique, peer-to-peer writing. The process is in the form of text exchanges, for example, with a peer to be corrected. The form is between students and students; one corrects others' results of writing that have been made by his friend (Boyd 2015). This process must remain under the guidance of the teacher. The teacher needs to emphasize to the students that they should be seriously correct their peers' writing based on a predetermined form of errors.

Walz and Date (1982) mention some benefits of peer-correction. They are:

a. It will reinforce the students' motivation in the language learning process.

b. It will render the students who are more active in the teaching-learning process.

c. Other students will more easily understand the correction given.

d. The students will perform more roles to be more active in the learning process.

The students' problem in writing is also caused by the difficulty of conveying ideas in writing (Ariyanti and Fitriana, 2017; Jabali, 2018). It is due to their inadequate knowledge of language elements such as vocabulary and grammar. In addition to these difficulties in writing itself, the students' reluctance may also bring problems in writing. Harmer (2004:61) states that "the students are reluctant to write because they rarely write, even in their language." The lack of practice to write can make the students undertake poor writing. Therefore, the teacher should apply appropriate techniques to facilitate students to improve or even solve their problems.

Peer correction is one of the techniques that may enable the students to work in pairs. The activity provides opinions and suggestions so that the students can receive feedback from their counterparts. Elmaadaway (2018) asserts that most practitioners believe that students' involvement in the classroom should be enhanced to better learning, and involvement increases when students give feedback to each other's products. The technique provides the students more opportunities to learn about their mistakes and the right way in order to improve the quality of their writing (Phuong 2019). In addition, Wilson and Czik (2016) state that students, certainly, await feedback on what they are establishing or what they have produced. The teacher has previously become the one who is responsible for assisting and fixing the students' works (Lorente-Catalán and Kirk, 2016). However, there are some other techniques that can lead to giving responses to students' works. The peer-correction technique is one of the reachable techniques.

In correcting students' writing drafts, a teacher should apply a technique that allows the learners to get comments and evaluations on knowledge and skills in writing. This is supported by the opinions of Johnson (2017) stating that peer-correction is a piece of a broad category of pedagogical activity which brings students into working together in groups (Yadollahi and Rahimi 2015). It is obvious that this addition of roles improves the learners' competence in the writing process. Therefore, this peer work technique gives them chances to compose writing without the teacher's direct involvement to correct their confusion or fallacy (Norman 2010). Moreover, corrective feedback focuses on giving students support in organizing their ideas rather than only correcting students' language errors in writing (Al-Jarrah 2016)

This section is dedicated to the significant literature resources that contributed to the research. The author should survey scholarly articles, books, and other sources relevant to the area of research, providing a description, summary, and critical evaluation of each work.

\subsection{Advantages of Using Peer Correction Technique}


The peer-correction technique possesses some advantages when it is implemented in teaching writing skills. One of the advantages is that it promotes students to stay motivated to conduct activities in the lesson or learning process (Moloudi, 2011; Risman and Nirwana, 2019). It encompasses other students, which may bring the students into obtaining their self-confidence. It establishes the students' awareness through the revision of their first draft. This condition makes the timing process of learning becomes useful (Covil, 2010: 220). The students acquire confidence, gain perspective, and practice their critical thinking skills, for they are enabled to read the text by peers (Lee, 1997:42).

The peer correction feedback technique involves the students becoming the central part of the teaching and learning process (Ahmad 2016). The students are encouraged to be more creative and more critical by providing constructive feedback to other peers; this technique allows them to assess their peers' draft in terms of organization, context, grammar, punctuation, and spelling, and style (Kuyyogsuy 2019). Several peer-correction technique procedures can be carried out when teaching descriptive writing text. At the beginning of teaching writing, the teacher explains the topic, gives examples, and uses appropriate tenses (Ramírez et al., 2018). The teacher explains how to create the text of a person and then asks them to make a text of the topic (Sham et al., 2016). After doing the writing, the teacher asks the students to correct their partner"s draft, which was done based on the editing form. They should correct the spelling, grammar, content, and organization of the text (Hussein 2015). They took some notes and corrected the mistakes that occurred. In the next meeting, about a different topic, give an example and the use of tense. The teacher explains how to create a text and then asks them to make a text. After doing the writing, the teacher asked the students to correct their partner's draft, which was done based on the editing form. They should correct the spelling, grammar, content, and organization of the text. They took some notes and corrected the mistakes that occurred.

In short, peer correction provides significant advantages to the students, both researchers, and proofreaders. They learn how to provide and obtain constructive comments, suggestions, and recommendations on their drafts.

\section{Methodology}

The design of this research used a quasi-experimental design (Gay,2006). It involved two groups; the experimental group treats by applying the peer correction technique while the control group without peer correction technique with one group pre-test and post-test design to reduce the student's mistake in writing recount text. The subjects of this study were the eleventh-year students of junior high school in Sidrap, Indonesia. There were 49 students who participated as a sample of the study who were selected by simple random sampling.

This research used two kinds of variables; namely, the independent variable $(X)$ is a peer correction technique, and the dependent variable $(\mathrm{Y})$ is a writing recount text. The researcher determined the object of the study consisting of the population was all individuals from whom the data were collected. The statistics referred to a collection of individuals with distinctive characteristics of concern in a study. Population statistics were not limited to a group of people but also animals or anything that concern us. Sukmadinata (2011:250) Suggested that a population is a large group and the territory of the scope of our research. The population of this research was 178 students, the senior high school in Sidrap, Indonesia, then applied a cluster random sampling technique of 178 students. The class was selected randomly. The researcher selected two classes as a sample of 24 students as the experimental group and 25 students as a control group. The numbers of the total sample were 49 students.

\section{Results and Discussion \\ 4.1 Results of the Research \\ 4.1.1 The Result of Pre-test}

In this stage, the students were asked to write a recount text based on the topic given by the researcher. The pre-test was given before doing the research. First, the researcher came to the chosen class and explained to the students what they were going to do. It begins by distributing the instrument and asking them to have a test in the pre-test 


\begin{tabular}{|c|c|c|c|c|}
\hline \multirow[t]{2}{*}{ Level } & \multicolumn{2}{|l|}{ Experimental } & \multicolumn{2}{|l|}{ Control } \\
\hline & Freq. $(F)$ & $\%$ & Freq. $(F)$ & $\%$ \\
\hline Excellent & - & & - & - \\
\hline Very good & - & - & 1 & $4 \%$ \\
\hline & & & 2 & $8 \%$ \\
\hline Good & 2 & $8,33 \%$ & & \\
\hline Fair & 9 & $37,5 \%$ & 9 & $36 \%$ \\
\hline Poor & 13 & $54,16 \%$ & 9 & $36 \%$ \\
\hline Very Poor & - & - & 4 & $16 \%$ \\
\hline Total & 24 & $100 \%$ & 25 & $100 \%$ \\
\hline
\end{tabular}

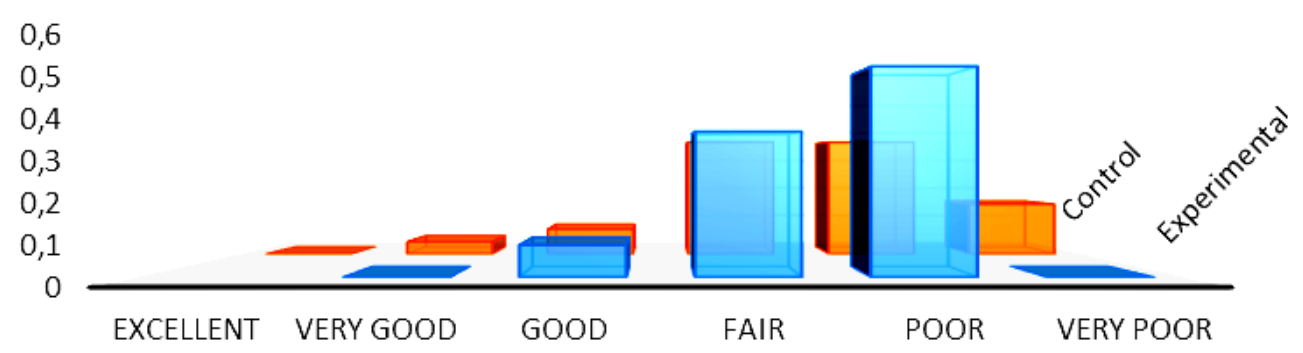

\begin{tabular}{|l|c|c|c|c|c|c|}
\cline { 2 - 7 } \multicolumn{1}{c|}{} & Excellent & Verygood & Good & Fair & Poor & Very Poor \\
\hline$\square$ Experimental & & 0 & $8,33 \%$ & $37,50 \%$ & $54,16 \%$ & 0 \\
\hline$\square$ Control & 0 & $4 \%$ & $8 \%$ & $36 \%$ & $36 \%$ & $16 \%$ \\
\hline
\end{tabular}

口Experimental $\square$ Control

Chart 1. The level achievement of experimental and control class on writing through corrective feedback in the pre-test.

Table 1 or Figure 1 shows the results of data processing in the pre-test; where the writing ability for the dominant experimental class experienced an achievement that was in a position between the poor to a fair level, i.e. $91.67 \%$, and only $8.33 \%$ of students whose writing achievement was in a good position. Achievements in this pre-test are categorized as a low achievement for the value of Indonesian education learning achievements that have a minimum average score of 79 . This also occurs in the control class that shows the dominant achievement of writing respondents is still low; it is $88 \%$ still at the poor level to a fair level, and only $12 \%$ are at good levels. From the conclusion, data in Table 1 or Figure 1 shows that the two research sample groups still have low achievement.

Table 2. Students' mean score of writing achievement in the pre-test

\begin{tabular}{lll}
\hline No & Types of Test & Mean Score \\
\hline 1 & Experimental Class & 61.25 \\
2 & Control Class & 60.88 \\
\hline
\end{tabular}


The average achievement of writing in both groups experiment and control class is also clearly stated in table 2 . The average score for writing achievement of the experimental class is 61.25 , and the average score of achievement for the control class is 60.88

\subsubsection{The Result of Post-test}

The post-test was conducted after all the treatments were given. In the post-test, the researcher knew or found out students' achievement in writing after giving pre-test and treatment.

Tabel 3. Students' achievement of writing composition in the post-test

\begin{tabular}{|c|c|c|c|c|}
\hline \multirow{2}{*}{ Level } & \multicolumn{2}{|c|}{ Experimental } & \multicolumn{2}{|l|}{ Control } \\
\hline & Freq. (F) & $\%$ & Freq. (F) & $\%$ \\
\hline Excellent & - & - & - & - \\
\hline Very good & 5 & $20,83 \%$ & 1 & $4 \%$ \\
\hline Good & 16 & $66,66 \%$ & 4 & $16 \%$ \\
\hline Fair & 3 & $12,5 \%$ & 8 & $32 \%$ \\
\hline Poor & - & - & 9 & $36 \%$ \\
\hline Very Poor & - & - & 3 & $12 \%$ \\
\hline Total & 24 & $100 \%$ & 25 & $100 \%$ \\
\hline
\end{tabular}

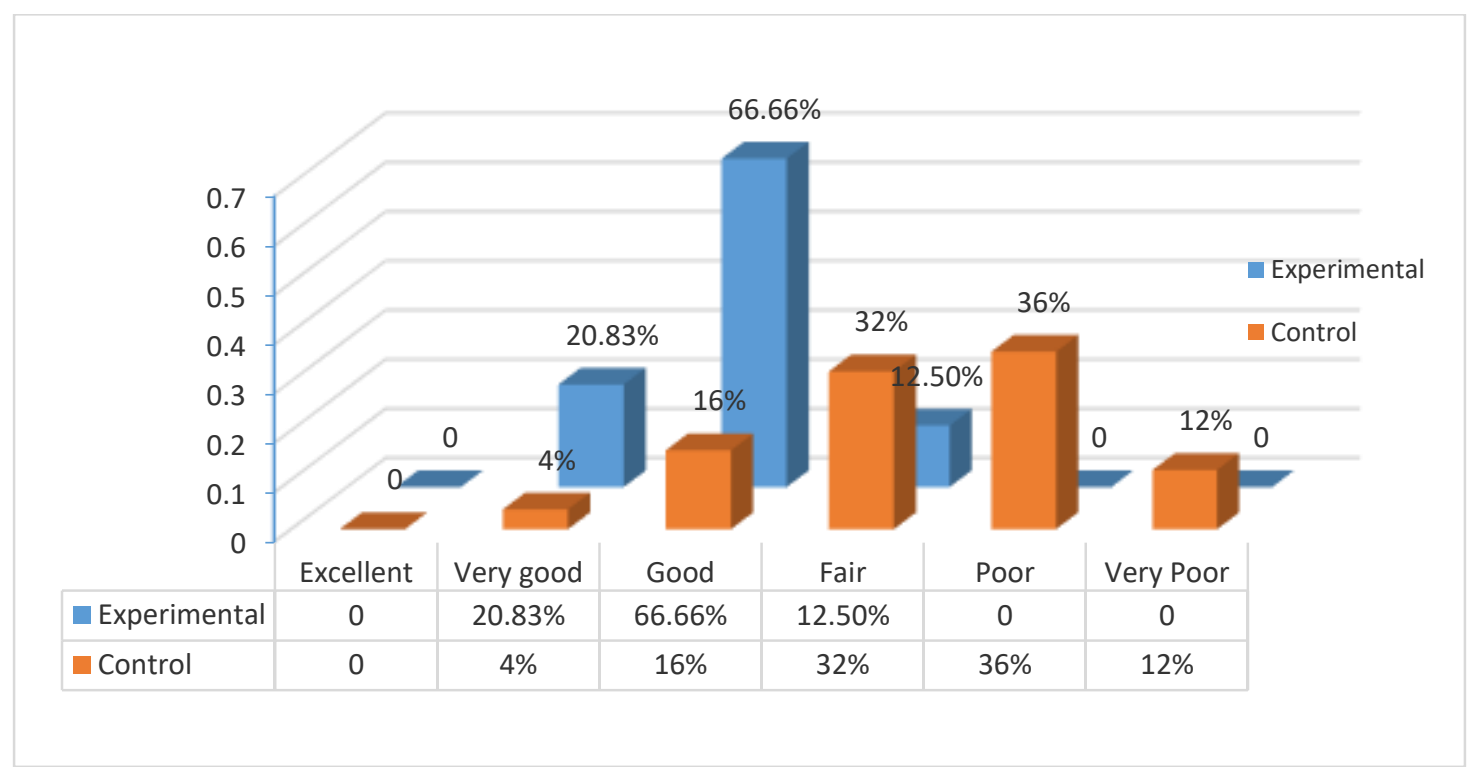

Chart 2. The level achievement of experimental and control class on writing through corrective feedback in the post-test.

Table 3 or Figure 2 explains the level of writing learning achievement in the experimental class that has increased significantly. Achievements in this experimental class showed $87,50 \%$ of respondents were at the level of good to very good and only $12,50 \%$ at the average level. However, the achievements for the poor and very poor level were not found at all. Likewise, the achievements in the control class also experienced a slight increase in writing achievement compared to the achievement in the pre-test. For the session in the post-test, the writing achievement for the control class was $20 \%$ of respondents had been in the level of good to very good, while the previous achievement in the pre-test was only $12 \%$ of respondents who were at the level of good to very good. 


\begin{tabular}{lll}
\hline No & Types of Test & Mean Score \\
\hline 1 & Experimental Class & 76.45 \\
2 & Control Class & 62.8 \\
\hline
\end{tabular}

The table above showed that the mean score obtained by the students for an experimental class in the post-test was 76.45, the standard deviation was 4.70, and the mean score of the control class was 62.8. Consequently, after giving treatment, the mean score of the pre-test, post-test for experimental, and control class above showed that the writing ability of the students was at a good level of achievement. Moreover, the score of the experimental class was higher than the score of the control class. The comparison data of the average score between the experimental and control groups means that the development of writing achievement in the experimental group is more improved compared to the control group after receiving learning treatment through the corrective feedback approach. On the other hand, corrective feedback is one of the practical approaches to teaching writing to Indonesian EFL learners.

Furthermore, the effectiveness level of the corrective feedback approach is revealed in the results of the statistical T-test analyst in Table 5 below.

\subsubsection{Hypothesis Testing}

In hypothesis testing, the researcher used the t-test formula. The level of significance is set at. In addition, with the degree of freedom $=47$. In the pre-test, it found that the t-table value (1.6779) is higher than the t-test 0.06$)$. In the post-test, it was found that the t-test value (7.18) is higher than the t-table value (1.6779). The analysis showed that the null hypothesis (Ho) is rejected and the alternative hypothesis $(\mathrm{H} 1)$ is accepted. It means that the student's achievement in writing recount text who were taught by using peer correction technique was better than the students' achievement who were taught without peer correction technique. Finally, the researcher concluded that the use of peer correction reduced student mistakes in teaching recount text at the eleventhyear students of senior high school of Sidrap regency in Indonesia.

Table 5. of T-test analysis in the pre-test and post-test

\begin{tabular}{llcc}
\hline Type Of test & Level significant & t-test value & t-table value \\
\hline Pre-test & 0,05 & 0.06 & 1.6779 \\
Post-test & 0,05 & 7.18 & 1.6779 \\
\hline
\end{tabular}

The description of the collected data through the test, as explained in the previous section, showed that the students' achievement in writing recount text after the treatment by using peer correction technique. The data is the writing test score for the students of Senior high school. It was indicated by the mean score of the post-test that was higher than the mean score of pre-test $(76.45>61.25)$ that applied in the experimental class.

\subsection{Discussion}

According to the research finding, the researcher found that the use of peer correction in teaching writing recount text is better than teaching without peer correction technique. The students' mistakes were reduced in writing recount text with peer correction technique.

The student's ability taught to use peer correction was good. The average score of the students' achievement who were taught by using peer correction was 76.45 included in good categorized. By peer correction, students found their ability in writing with the got idea, feeling, and express into writing. Different themes each meeting got time students to express their ideas freely, and the teacher could create a representative and exciting in the teaching-learning process.

Peer correction was a technique that enabled the students' work in pairs. It gave opinions and suggestions so that the students could get feedback from their partners. Calsiyao (2015) conducted an investigation of learner attitudes toward corrective feedback in the classroom of spoken language errors among language learners at Kalinga-Apayao State College. The number of samples 
involved was 365 respondents and used a questionnaire as a tool to collect learner perception data on corrective feedback on errors-spoken language in the classroom. The questionnaire was used as a tool to collect data. This study showed that students preferred the three types of correcting techniques: teacher correction, peer correction, and peer correction. (Azarnoosh 2013) conducted a research project, which compared peer assessment of English university students' corrections. It also investigates the possibility of causing a bias in the assessment results due to the closeness between the student as the assessor and the student being assessed as well as the impact of this form of assessment action on students' attitudes. The study involved 38 English students who passed the writing course, took the skills test and filled out the pre-questionnaire. The paired sample t-test and chisquare were applied to analyze the collected data. The study of Azarnoosh revealed that there is no significant difference between the learners' peer assessment and the teacher assessment. No friendship bias was found in peer assessment, but this practice led to the change in students' attitudes towards a positive perception of peer assessment.

This technique gave the students more chances to know about their mistakes and the right way in order to make their writing better. In correcting students' drafts, a technique enables the students to get feedback on knowledge. Peer correction was a technique where the students corrected their drafts in pairs. Each pair will check the draft and correct the mistakes based on what they have known. It was implemented to write a recount text

The student's ability taught without using peer correction was fair. The average score of the students' achievement who were taught without using peer correction was 62.8 included in fair categorized. It can see the students' post-test results after they gave treatment without a peer correction technique with no significant score. It means that teaching writing recount text without peer correction was not effective in reducing students' mistakes.

After giving treatment, three times, there were significant differences in achievement in writing recount text for both classes. There were improvements in the student's scores from pre-test to post-test for the experimental class and no significant improvement for the controlled class. The researcher found a significant effect on the use of peer correction techniques. From the mean score of the post-test obtained, the students in the experimental class were (76.45) with the result-standard deviation (4.70), and the mean score of the controlled class was (62.8) the result-standard deviation (8.02). After analyzing the t-test formula, the result of the t-test value of the post-test (7.18) is higher than the t-table value (1.67) for 0,05 (5\%) level of significance, degree freedom df $(n 1+n 2-2) 47$. Based on criteria of the testing hypothesis that interpreted that statically hypothesis, so the researcher concludes that the null hypothesis $(\mathrm{HO})$ is rejected with interpretation value $\mathrm{t}$-table $(1.67) \leq$ value $\mathrm{t}$-test $(7.18)$, and the alternative hypothesis $(\mathrm{H} 1)$ is accepted with interpretation value-t-test (7.18) $\geq$ value $t$-table (1.67). It means that the achievement of the students who were treated through peer correction can reduce and find out students' mistakes in writing recount text in the senior high school in Sidrap, Indonesia.

\section{Conclusions}

The researcher concludes that the use of peer correction is useful to reduce the students' mistakes. It was supported by the mean score of the student who was taught by using peer correction post-test was higher (76.45), than the mean score of the pre-test (61.25). In the table of achievements, it was in the range of 71-80, which is categorized as good. Then, the mean score of the students who were taught writing recount text without peer correction post-test was 62.8 , and the pre-test was 60.88 , which were categorized as fair.

Applying the t-test (7.18) is higher than the $t$-table value (1.67). From the result of responses, it concluded that there was a significant difference in achievement between the students who were taught writing recount text by using peer correction and the students who were taught writing recount text without using peer correction technique from the t-test calculated.

From the use of peer correction techniques, it can be concluded that all students can be involved. Students look happy, relaxed, and feel more careful in writing the next poem. With the peer correction techniques, students can use language effectively so that it becomes good and correct writing. Students must double-check their writing in order to ensure that the writing is correct. With peer correction techniques, directly students will be able to use effective language so that it becomes good and correct writing. Teachers and students need to review errors in narrative writing that result from writing training processes.

\section{Pedagogical Implication}

The results of this study, theoretically, have implications that learning the ability to write Indonesian with peer correction techniques can be used to increase student involvement in the assessment activities of scientific papers or daily writing assignments. This study provides a further pedagogical impact in the form of increased learning activities and student achievement in writing courses. The results of the study have practical implications that the use of varied learning methods can be used as a great way for teachers to improve the quality of learning and to increase the confident character of the ability to assess the work of colleagues or their own in standardized writing form (Ko and Sammons 2012). (Darling-Hammond et al. 2019) stated that the teacher should be 
innovated on teaching development; the traditional learning models and environments are the main component tube a priority to hands-on experiences" through the use of science kits. The quality improvement is in the form of more independent and meaningful writing activities for students (Genç 2016).

Moreover, the results of this study have provided useful information to overcome problems in using sentences or correct grammar. Peer correction is one of the ways that can motivate the teacher and students to work on writing activities. This technique can be carried out directly and continuously (Banaruee et al. 2018). It is also expected for the student to minimize errors in composing a sentence so that it can produce exciting writing compositions Mahmoud (Itmeizeh 2016).

\section{Recommendation}

Regarding the conclusions of the results, the researcher makes some recommendations. First, students should be more active and participate in each learning activity with a feeling of pleasure. (Rodriguez et al. 2015) stated that feeling pleasure is a form manifestation of a learning activity that has a function to gather information. In addition, students should have more chances to practice writing in order to produce good writing (Rao 2018). Second, English teachers should be able to deliver peer-correction techniques in teaching other writing learning materials, not only in writing scientific papers. In addition, the teacher should provide more opportunities for students to practice their writing skills so that the quality of student writing results improves. Third, the school should add teaching-learning facilities or facilities to support and optimize learning activities. In addition, the school should better motivate and facilitate teachers in improving their teaching abilities. Fourth, other researchers are expected to be able to collaborate actively with teachers to apply new learning methods that are innovative and involve students in learning activities so that students' talents, potential, and creativity can develop well.

\section{References}

[1] Ahmad, N. (2016). Vision \& Wisdom for an Effective Teaching of English as a Foreign Language with Reference to the Students of University of Bisha, Saudi Arabia. 5(1):1-19.

[2] Al-Jarrah, R. S. (2016). A Suggested Model of Corrective Feedback Provision. Ampersand 3:98-107.

[3] Al-saleh, N. A. (2018). Corrective Feedback. 1-121.

[4] Amara, N. (2015). Errors Correction in Foreign Language Teaching. The Online Journal of New Horizons in Education 5(3):58-68.

[5] Arifin, M. A. \& As'Ad, M. S. (2019). Student Engagement, Collaborative Learning, and Flipped Classroom as a Basis for a Blended Language Learning Environment. Asian EFL Journal 24(4):38-44.

[6] Ariyanti, A. \& Fitriana, R. (2017). EFL Students' Difficulties and Needs in Essay Writing. 158 (Ictte):111-21.

[7] Astawa, N. L. P. N. S. P., Artini, L.P., \& Nitiasih, P. K.. (2017). Project-Based Learning Activities and EFL Students' Productive Skills in English. Journal of Language Teaching and Research 8(6):1147.

[8] Ayu, G. \& Ari A. (2018). Using Self-Assessment to Assess Rural Young Learners' Writing Skills in English Foreign Language Classroom. Journal of Applied Studies in Language 2(2):109-15.

[9] Azarnoosh, M. (2013). Peer Assessment in an EFL Context: Attitudes and Friendship Bias. Language Testing in Asia 3(1):1-10.

[10] Badcock, C. \& Stoller R. J. (1989). Presentations of Gender. The British Journal of Sociology 40(2):350.

[11] Banaruee, H., Khatin-Zadeh, O., \& Ruegg, R.. (2018). Recasts vs. Direct Corrective Feedback on Writing Performance of High School EFL Learners. Cogent Education 5(1).

[12] Boyd, M. P. (2015). Relations Between Teacher Questioning and Student Talk in One Elementary ELL Classroom. Journal of Literacy Research 47(3):370-404.

[13] Brown, H. D. (2001). Teaching by Principle and Interactive Approach to Language Pedagogy. New York: Longman

[14] Byrne, D. (1993). Teaching Writing Skills. New York: Longman

[15] Calsiyao, I. (2015). Corrective Feedback in Classroom Oral Errors among Kalinga-Apayao State College Students. International Journal of Social Science and Humanities Research 3(1):394-400.

[16] Carosotto, C. (2017). "Writing in Journals as a Tool for Expressing Ourselves: A 6-8 Week Long Writing Curriculum for a 3rd / 4th Grade, Self-Contained, Special Education Classroom

[17] Darling-Hammond, L. (2017). Effective Teacher Professional Development. Palo Alto, CA: Learning Policy Institut (June):1-2.

[18] Darling-Hammond, L., Flook, L., Cook-Harvey, C, Barron, B., \& Osher, D. (2019). Implications for Educational Practice of the Science of Learning and Development. Applied Developmental Science 0(0):1-44.

[19] E Ackerman, C. (2019). "Courtney."

[20] Elmaadaway, M. A. N. (2018). The Effects of a Flipped Classroom Approach on Class Engagement and Skill Performance in a Blackboard Course. British Journal of Educational Technology 49(3):479-91.

[21] Fadhly.F.Z., \& Ratnaningsih, N. (2018). Reconstruction of Cognitive Process in Popular Article Writing. The Asian EFL Journal 20(5):7-33

[22] Faradhibah, R. \& Nur, N. A. (2017). Analyzing Students' Difficulties in Maintaining Their Coherence and Cohesion in Writing Process. ETERNAL (English, Teaching, Learning and Research Journal) 3(2):179-89.

[23] Fareed, M., Ashraf, A., \& Bilal, M.. (2016). ESL Learners' Writing Skills: Problems, Factors, and Suggestions. Journal of Education \& Social Sciences 4(2):83-94.

[24] Genç, Z. S.. (2016). More Practice for Pre-Service Teachers and More Theory for In-Service Teachers of English Language. Procedia - Social and Behavioral Sciences 232(April):677-83.

[25] Genlott, A. A.i and Grönlund, Å. (2013). Improving Literacy Skills through Learning Reading by Writing: The IWTR Method Presented and 
Tested. Computers and Education. 67:98-104.

[26] Gestanti, Nimasari, \& Mufanti. (2019). Reoverviewing Google Translate Result and Its Implication. Asian EFL Journal Asian EFL Journal 23(3.2):128-39.

[27] Hajan, B. H., Hajan.B.C., \& Marasigan. A. (2019). Second Language Academic Writing: A study of Teachers Belief and Pedagogical Practices in Senior High School. Asian EFL Journal. 21(2.3):9-35.

[28] Harmer, J. (2007). How to Teach English. England: Pearson Education Limited.

[29] Harris, K. R. \& Graham, S. (2016). Self-Regulated Strategy Development in Writing: Policy Implications of an Evidence-Based Practice. Policy Insights from the Behavioral and Brain Sciences 3(1):77-84.

[30] Hussein, H. (2015). The Effect Of A Proposed Strategy-Based Writing Model On EFL Learners' Writing Skills Hussein. International Journal of English Language Teaching. 3(4):98-224.

[31] Hyland, K. (2016). Methods and Methodologies in Second Language Writing Research. System 59:116-25.

[32] Alfaki, I. M. (2015). University Students' English Writing Problems: Diagnosis and Remedy. International Journal of English Language Teaching. (Www.Eajournals.Org) 3(3):40-52.

[33] Imaniah, I. and Mayuni, I. Lustyantie, N. (2019). The Student's Academic Writing Skill in Terms of Academic Procrastination, Self Esteem and Reading Habit at the Muhammadiyah University of Tangerang. Asian EFL Journal 24(4):118-27.

[34] Ines, B. Z. (2017). Error Correction in the Early Stages of Second Language Learning. International Journal of Academic Research in Business and Social Sciences 7(1):164-77.

[35] Ismail, N., Hussin, S., \& Darus, S.. (2012). ESL Tertiary Students' Writing Problems and Needs: Suggested Elements for an Additional Online Writing Program (IQ-Write) for the BEL 311 Course. International Journal of Learning 18(9):69-80.

[36] Jabali, O. (2018). Students' Attitudes towards EFL University Writing: A Case Study at An-Najah National University, Palestine. Heliyon 4(11):e00896.

[37] Jacobson-Lundeberg, V.. (2016). Pedagogical Implementation of 21st Century Skills. Educational Leadership and Administration: Teaching and Program Development 27:82-100.

[38] Jingjing, M.. (2017). Classroom Writing Assessment and Feedback in L2 School Contexts. The Asian EFL Journal 978-81.

[39] Johnson, S. J. (2017). Multimodality and Footing in Peer Correction in Reading Picture Books. Linguistics and Education 41:20-34.

[40] Jordan, R. R., Beaumont, M., Cawood, G, Cullen, C, James, K, Jordan, J. Matthews, A., Brien, T. O., \& Sim, D. (1990). Academic Writing Course Outline.Pdf.

Harackiewicz, J. M. Smith, J.L., \& Priniski, S.J.. (2016). Interest MAtter: The Importance of Promoting Interest in Education. Policy Insight Behav Brain SCI. 3(2) 220-227.

[41] Kennedy, E. \& Shiel, G.. (2019). Writing Pedagogy in the Senior Primary Classes Knowledge, Skills and Processes for Writing. Educational Research Center

[42] Ko, J. \& Sammons, P. (2012). Effective Teaching: A Review of Research and Evidence." CfBT Education Trust 56.

[43] Kuyyogsuy, S. (2019). Promoting Peer Feedback in Developing Students' English Writing Ability in L2 Writing Class. International Education Studies 12(9):76.

[44] Lalam, E. M.. (2019). Essay Writing Difficulties Encountered by EFL Learners.

[45] Latifa, A., Nur, Rafi'ah, \& Amaluddin (2019). Utilizing Google Classroom Application to Teach Speaking to Indonesian EFL Learners. Asian EFL Journal 24(4):176-94.

[46] Latifa, A., Ernawati, \& Budiman, N. (2020). Increasing the Students' Ability in Writing Announcements through Guided Writing Technique. Asian-EFL-Journal 27(3.2) 61-82.

[47] Lorente-Catalán, E. and Kirk, D. (2016). Student Teachers' Understanding and Application of Assessment for Learning during a Physical Education Teacher Education Course. European Physical Education Review 22(1):65-81.

[48] Maskor, Z. M. \& Baharudin, H.. (2016). Receptive Vocabulary Knowledge or Productive Vocabulary Knowledge in Writing Skill, Which One Important? International Journal of Academic Research in Business and Social Sciences 6(11):261-71.

[49] García, E. M. \& Martínez, V. G. M.. (2018). Students' Reactions to Teacher Corrective Feedback to Oral Production: A Study on SelfCorrection and Autonomy in Compulsory EFL University Courses. MEXTESOL Journal 42(1):1-24.

[50] Moloudi, M.. (2011). Online and Face-to-Face Peer Review: Measures of Implementation in ESL Writing Classes. The Asian EFL Journal 5(2):4-23.

[51] Nona \& Chalak. (2016). The Effect of Employing Electronic Peer Assessment on Iranian EFL Learners' Writing Ability and Autonomy. Theory and Practice in Language Studies 6(12):2272.

[52] Norman, D. A. (2010). The Way I See It looking Back, Looking Forward. Interactions 17(6):61.

[53] Oshima, A., and Hogue, A.. (2006). Writing Academic English. Fourth ed. The Pearson Longman Academic.

[54] Phuong, T. T. H. P. \& Duyen. (2019). Effect of Medical English on Students' General English Proficiency. The Asian EFL Journal 15(2).

[55] Ramírez, B>, Irais \& Cuamatzi, P.M.G.. (2018). Self and Peer Correction to Improve College Students' Writing Skills. Profile: Issues in Teachers' Professional Development 20(2):179-94.

[56] Rao, V. C. S. (2018). The Use of English Language in Research." Journal for Research Scholars and Professionals of English Language Teaching 2(8).

[57] Rivers, W. M. (1968). Teaching Foreign Language Skills. second. edited by wilga M. Rivers. The University of Chicago Press.

[58] Rodriguez.I, Meseguer.A.A., Artola. (2015). E-Learning Continuance: The Impact of Interactivity and the Mediating Role of Imagery, Presence, and Flow. Information and Management 53:504-516.

[59] Sadeghi, K. \& Jack C. R.. (2016). The Idea of English in Iran: An Example from Urmia. Journal of Multilingual and Multicultural Development 37(4):419-34.

[60] V Satya Sekhar, S. D. \& Rao, C. S. (2018). Developing Students 'Writing Skills in English-A Process Approach. Journal for Research Scholars and Professionals of English Language Teaching 2(6):1-6.

[61] Sham, J., Zehan N., and Daud, M.. (2016). Corrective Feedback Improves Students ' Writing Skill in ESL: A Quasi-Experimental to Language 
Pedagogy. (March).

[62] Sharp, L. A. (2016). Acts of Writing: A Compilation of Six Models That Define the Processes of Writing. International Journal of Instruction. 9(2):77-90.

[63] Stefano. (2020). "Communication Skills in a Foreign Language: Achieve Fluency by Solving Tasks. accessed from https://www.thinkinitalian.com/communication-skills-foreign-language/

[64] Troia, G. A. \& Steve G.. (2004). Students Who Are Exceptional and Writing Disabilities: Prevention, Practice, Intervention, and Assessment. Exceptionality 12(1):1-2.

[65] Ullmann, T. D.. (2019). Automated Analysis of Reflection in Writing: Validating Machine Learning Approaches. International Journal of Artificial Intelligence in Education 29(2):217-57.

[66] Vermeir, P., D. Vandijck, S. Degroote, R. Peleman, R. Verhaeghe, E. Mortier, G. Hallaert, S. Van Daele, W. Buylaert, \& D. Vogelaers. 2015. Communication in Healthcare: A Narrative Review of the Literature and Practical Recommendations. International Journal of Clinical Practice. 69(11):1257-67.

[67] Walz, J. C. \& B. Date. (1982). Error Correction Techniques for the Foreign Language Classroom. Language in Education: Theory and Practice No. 50. Washington DC: Center for Applied Linguistics.

[68] Wanci, R. and Darwis N. (2019). "Analyzing In-Service And Pre-Service Teachers' Perceptions On Peer Reflection At lain Bone." Asian EFL Journal Research 23(3.4):128-39.

[69] Westmacott, A.. (2017). Direct vs. Indirect Written Corrective Feedback: Student Perceptions. Ikala 22(1):17-32.

[70] Wilson, J. and Czik, A.. 2016. Automated Essay Evaluation Software in English Language Arts Classrooms: Effects on Teacher Feedback, Student Motivation, and Writing Quality. Computers and Education 100:94-109.

[71] Yadollahi, H. and Rahimi, Ali. 2015. "The Effects of Different Task Types on Learners' Performance in Collaborative Virtual Learning Environment. Procedia - Social and Behavioral Sciences 176:667-73.

[72] Ying, Z. (2018). Exploring Construction of College English Writing Course from the Perspective of Output-Driven Hypothesis. English Language Teaching. 11(2):188-92.

[73] Zeng, X. (2016). On the Improvement of College English Writing through Integration of Language Skills. Proceeding of the Sixth International Conference on Electronic Mechanical Information, and Management Society. (Emim):1820-23. 